\title{
Zika Virus Infection and Immuno-Cross-Reactivity to Dengue: An Issue in the Pathogenesis of Congenital Microcephaly
}

\author{
Sora Yasri,, ${ }^{1,}$ and Viroj Wiwanikit ${ }^{2}$ \\ ${ }^{1}$ KMT Primary Care Center, Bangkok, Thailand \\ ${ }^{2}$ Hainan Medical University, Hainan, China \\ "Corresponding author: Sora Yasri, KMT Primary Care Center, Bangkok, Thailand. Tel: +66-24789678, E-mail: sorayasri@outlook.co.th \\ Received 2016 August 17; Accepted 2016 August 18.
}

Keywords: Zika Virus Infection, Immuno-Cross-Reactivity, Dengue, Pathogenesis, Congenital Microcephaly

\section{Dear Editor,}

Zika virus infection is currently a global medical concern. The infection is already seen in many tropical countries and the main concern is the congenital microcephaly due to infection in pregnant mothers. It is believed that the direct viral invasion causes the neuropathology (1) and the involvement occurs in stem cells during the organogenesis phase (2). A recent study showed an interesting finding that "dengue virus sero-cross-reactivity drives antibody-dependent enhancement of infection with zika virus" (3). It was mentioned that the immuno-cross-reactivity to dengue was an important factor leading to congenital anomaly problems (3).

However, there is still a myth regarding the epidemiological discrepancies of the congenital anomaly incidence in South America and other areas of the world (4). This cannot be explained by the immunopathogenesis due to immunocross-reactivity theory. In fact, other additional factors such as different specific environmental insult as well as genetic factors in different settings might be the cause of the problem in South America and this is an issue for further studies (5).

\section{References}

1. Wiwanitkit V. Zika virus and pregnancy. J Matern Fetal Neonatal Med. 2016:1. doi:10.1080/14767058.2016.1197901. [PubMed: 27265775].

2. Liang Q, Luo Z, Zeng J, Chen W, Foo SS, Lee SA, et al. Zika Virus NS4A and NS4B Proteins Deregulate Akt-mTOR Signaling in Human Fetal Neural Stem Cells to Inhibit Neurogenesis and Induce Autophagy. Cell Stem Cell. 2016 doi: 10.1016/j.stem.2016.07.019. [PubMed: 27524440].

3. Dejnirattisai W, Supasa P, Wongwiwat W, Rouvinski A, Barba-Spaeth G, Duangchinda T, et al. Dengue virus sero-cross-reactivity drives antibodydependent enhancement of infection with zika virus. Nat Immunol. 2016;17(9):1102-8. doi: 10.1038/ni.3515. [PubMed: 27339099].

4. Sriwijitalai W, Wiwanitkit V.Zika Virus Infection in Pregnant Women: Topic for Discussion. Rev Bras Ginecol Obstet. 2016;38(6):314. doi: 10.1055/s-00361584947. [PubMed: 27399927].

5. Collucci C. Brazil to investigate if other factors act with Zika to cause congenital defects. BMJ. 2016;354:i4439. doi: 10.1136/bmj.i4439. [PubMed: $27515384]$. 